\title{
Comparative study of diesel engine performance and emission with soybean and waste oil biodiesel fuels
}

\author{
A.K. Azad ${ }^{1 *}$, M.G. Rasul ${ }^{1}$, Brady Giannangelo ${ }^{1}$ and Rubayat Islam ${ }^{2}$ \\ ${ }^{1}$ School of Engineering and Technology, Central Queensland University, \\ Rockhampton, QLD 4702, Australia. \\ ${ }^{2}$ Department of Mechanical Engineering, Bangladesh University of Engineering and \\ Technology, Dhaka -1000, Bangladesh \\ *Email: a.k.azad@cqu.edu.au or azad.cqu@gmail.com,m.rasul@cqu.edu.au \\ Phone: +61 469235722 .
}

\begin{abstract}
The study investigated the engine performance and emission using biodiesel from soybean oil and waste cooking oil. The fuel properties of these biodiesels were determined using ASTM D6751and EN 14214 standards. The fuels were tested in a multi-cylinder diesel engine with an electromagnetic dynamometer and a 5-gas analyser was used for emission analysis. The result shows that the thermal performance of the engine slightly decreases with increase of the biodiesel blends ratio (i.e. B5, B10, B15, B20 and B50). On the other hand, emission decreases with the increase of biodiesel blends. The reduction in emissions was different for both biodiesels. Waste oil biodiesel showed better trends of emissions reduction with increase of the biodiesel percentage compared with soybean biodiesel. The brake specific fuel consumption (BSFC) of both biodiesels is $(6.05 \%, 9.13 \%, 12.36 \%$ and $18.57 \%$ for soybean) and $(8.17 \%, 11.40 \%$, $17.71 \%$ and $14.96 \%$ for waste cooking oil) higher than diesel, respectively. However, soybean biodiesel consumed less fuel and produced more power and torque compared to waste oil biodiesel. The study concluded that B10 soybean biodiesel blend produced more consistent and expected results than waste oil biodiesel from the performance and emission point of view.
\end{abstract}

Keywords: Biodiesel; waste cooking oil biodiesel; soybean biodiesel; exhaust emission, BSFC.

\section{INTRODUCTION}

Biodiesel is an eco-friendly and renewable source of energy for compression ignition (CI) engines. It can be a potential and sustainable alternative source of fossil fuel with significantly lower emission of greenhouse gases [1]. To determine the suitability of this biodiesel as an alternative source of energy for the CI engine is an interesting research topic today. The use of biodiesel is not new. It was first used by Rudolf Diesel, the inventor of the internal combustion engine, in 1900 [2]. He validated his engine by peanut vegetable oil. At present, most diesel engines run on petroleum-based diesel fuel as it has been cheaper to produce. The energy demand is increasing daily. This increasing energy demand should be met by a cleaner source of energy [3, 4]. Biodiesel is made from renewable plant or animal fats (tallow) that contain fatty acids [5-8], which can be converted into biodiesel using the transesterification reaction $[9,10]$. Biodiesel can also be produced from a wide array of feedstocks such as waste cooking 
oil, edible and non-edible oil seeds, wood and wood waste etc. [11-13]. Research and development is also ongoing to produce biodiesel from microalgae [14]; however, this is still in the development stage. Biodiesel can be used directly in diesel engines or it can be blended with diesel at different strengths [15]. The common way to state biodiesel blends is denoted by the letter B followed by the percent of biodiesel in the fuel [16]. For example, a fuel that has $20 \%$ biodiesel will be denoted by B20. When comparing biodiesel to petroleum-based diesel fuel, it is clearly evident that biodiesel is a lot more environmentally friendly [17-22]. A study sponsored by the United States Department of Agriculture and Department of Energy revealed that "Biodiesel yields 3.2 units of fuel product energy for every unit of fossil energy consumed in its life cycle. The production of B20 yields 0.98 units of fuel product energy for every unit of fossil energy consumed" [23]. In the literature it is reported that biodiesel is able to save the environment by reducing harmful emissions, and it can also contribute to the economy $[17,24,25]$. Biodiesel is characterised in generations, namely, first, second and third generation [26]. First generation biodiesel is produced from edible food crops such as mustard oil [27, 28], canola oil [29], sunflower oil etc. [30, 31]. Second generation biodiesel is produced from non-edible feedstocks [32-39]. As food crops are not used to make second generation biodiesel, this type of fuel is more commonly used because it is a more efficient and viable option [40,41]. Third generation biodiesel is produced from microalgae [14, 42-46]. The research on biodiesel is important from the socio-economic and environmental points of view.

The paper presents a comparative study of engine performance and emission using first generation (soybean) and second generation (waste cooking) biodiesel blends like B5, B10, B15, B20 and B50 with ultra-low sulphur diesel. An experimental study has been conducted on a 4-stroke, 4-cylinder diesel engine fuelled with soybean biodiesel and waste oil biodiesel. Engine performance parameters and emission parameters have been measured and compared with the performance and emission of diesel fuel. The study aims to identify better blends for mining industry engines in Australia.

\section{MATERIALS AND METHODS}

\section{Materials}

Soybean biodiesel was supplied by National Biodiesel Limited [47], a leading Australian supplier of premium quality biodiesel. The second biodiesel was produced from waste cooking oil, supplied by Central Queensland Technical and Further Education (TAFE) in Mackay, Australia. The biodiesel was blended with petroleum diesel which was used for engine testing.

\section{Fuel Properties of Biodiesel}

Analysis of the physical and chemical fuel properties of the biodiesel is very important before use in CI engines. The engine performance and exhaust gas emission depend on the fuel properties, namely density, viscosity, calorific value, cetane number, flash point, pour point etc. These were measured according to the ASTM D6751 and EN 14214 standards. These properties were compared with standard biodiesel and petroleum diesel. The properties of the fuels are presented in Table 1, which shows that almost every property of the fuels is within the acceptable range. The biodiesels have higher density than petroleum diesel, but it has some good fuel properties like higher flash point, pour point and cloud point. 
Table 1. Comparison of fuel properties of biodiesels with fossil diesel [10, 48].

\begin{tabular}{|c|c|c|c|c|c|}
\hline Properties & Unit & Diesel & $\begin{array}{l}\text { Soybean } \\
\text { biodiesel }\end{array}$ & $\begin{array}{l}\text { Waste oil } \\
\text { biodiesel }\end{array}$ & $\begin{array}{l}\text { Standard } \\
\text { biodiesel }\end{array}$ \\
\hline $\begin{array}{l}\text { Density at } \\
15^{\circ} \mathrm{C}\end{array}$ & $\mathrm{kg} / \mathrm{m}^{3}$ & 827.2 & 885 & $875-900$ & 880 \\
\hline Viscosity & $\mathrm{mm}^{2} / \mathrm{s}$ & 3.23 & 4.08 & 3.77 & $1.9-6.0$ \\
\hline $\begin{array}{l}\text { Calorific } \\
\text { value }\end{array}$ & $\mathrm{MJ} / \mathrm{kg}$ & 47.5 & 39.76 & 39.78 & - \\
\hline $\begin{array}{l}\text { Cetane } \\
\text { number }\end{array}$ & - & 58 & $47-52$ & 39-44 & 47 \\
\hline Flash point & ${ }^{\circ} \mathrm{C}$ & 68.5 & 69 & - & 130 \\
\hline Pour point & ${ }^{\circ} \mathrm{C}$ & 0 & -3 & - & -16 \\
\hline Cloud point & ${ }^{\circ} \mathrm{C}$ & 5 & -4 & - & -3 to -12 \\
\hline
\end{tabular}

\section{Biodiesel Blending}

The test biodiesels were blended with ultra-low sulphur diesel in different proportions. For both fuels, the blend samples were prepared by blending 5\% biodiesel and 95\% diesel denoted as B5, 10\% biodiesel with $90 \%$ diesel referred to as B10, $20 \%$ biodiesel and $80 \%$ diesel presented as B20 and 50\% biodiesel with 50\% diesel denoted as B50.

\section{Test Engine Setup}

A Kubota 4-stroke diesel engine was used as the test engine for this study. More specifically the engine is a Kubota V3300 diesel engine with a bore of $98 \mathrm{~mm}$ and a stroke of $110 \mathrm{~mm}$. The rated power output of the engine is $50.7 \mathrm{~kW}$ at $2600 \mathrm{rpm}$ and the rated torque is $230 \mathrm{Nm}$ at $1400 \mathrm{rpm}$. The dynamometer used for testing is a Dyno Dynamics engine dynamometer. It works by placing a load on the engine and then measuring the amount of power the engine produces against the load. The dynamometer is coupled with a test bed engine controlled by a computer. The schematic diagram of the test bed engine is presented in Figure 1. Table 2 presents the detailed specification of the test engine and dynamometer.

Table 2. Detailed specification of the test bed engine.

\begin{tabular}{lll}
\hline Items & Unit & Specifications \\
\hline Type & - & Vertical, 4-stroke, liquid-cooled \\
No. of cylinders & - & 4 \\
Bore & $\mathrm{mm}$ & 98 \\
Stroke & $\mathrm{mm}$ & 110 \\
Total displacement & $\mathrm{L}$ & 3.318 \\
Combustion type & - & Spherical type (E-TVCS) \\
Rated speed & $\mathrm{rpm}$ & 2800 \\
Compression ratio & - & $22.6: 1$ \\
Rated power & $\mathrm{kW}$ & 53.9 \\
Fuel injection timing & - & $16^{\circ}$ before TDC \\
Injection pressure & $\mathrm{MPa}$ & 13.73 \\
\hline
\end{tabular}




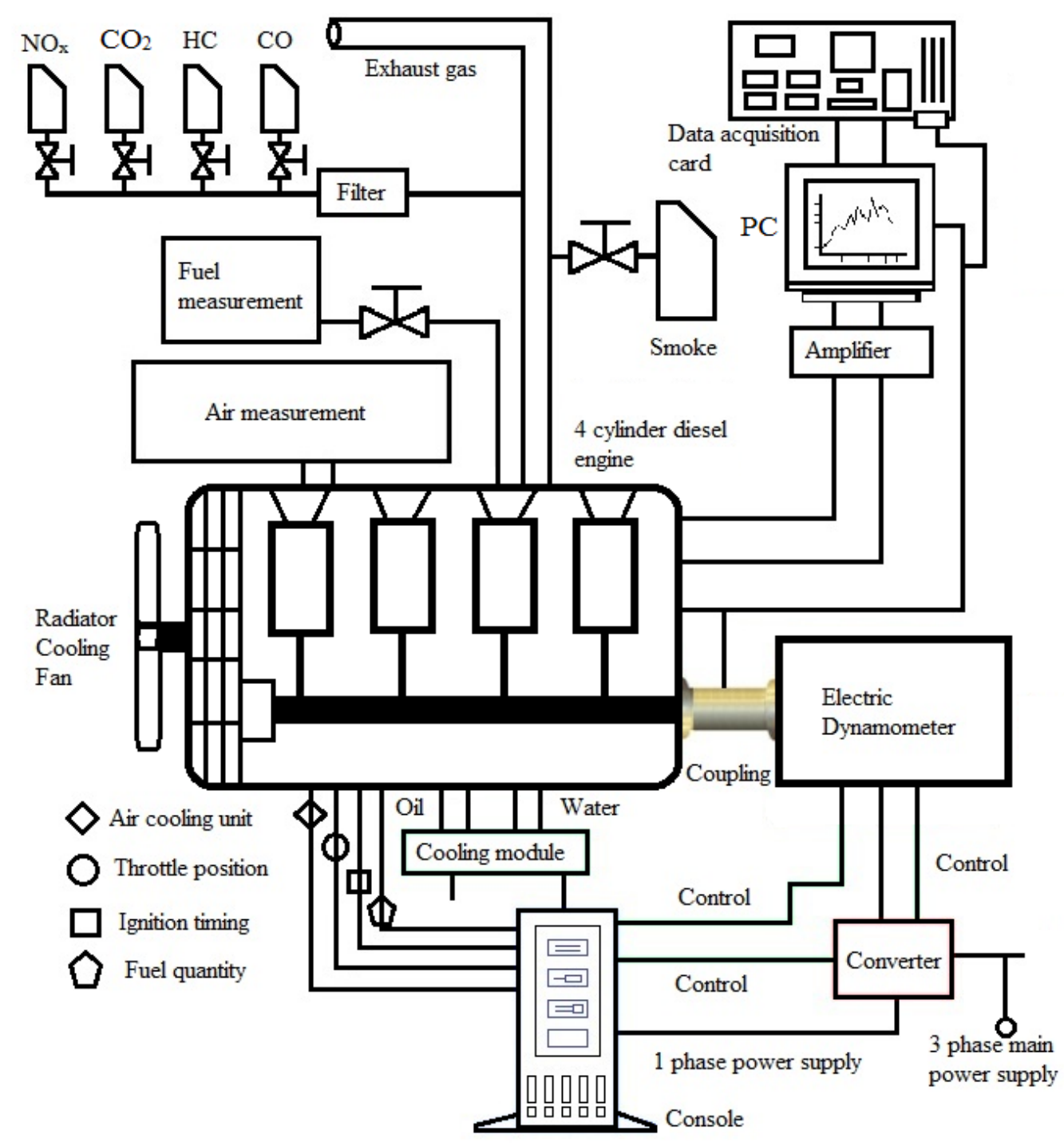

Figure 1. Schematic diagram of the test bed engine setup.

The exhaust gas analyser (EGA) used during testing is an Andros 6241A 5-gas analyser. This EGA takes instantaneous readings of the exhaust gas and can measure carbon monoxide, carbon dioxide and hydrocarbons using a non-dispersive infrared (NDIR) sensor. The EGA can also measure oxygen and nitrogen oxides using an electrochemical sensor. More information like the measurement range, resolution and accuracy of the EGA is presented in Table 3.

Table 3. Detailed specification of the EGA.

\begin{tabular}{|c|c|c|c|}
\hline \multirow[t]{2}{*}{ Measured gas } & \multicolumn{3}{|c|}{ Measurement } \\
\hline & Range & Resolution & Accuracy \\
\hline $\mathrm{HC}$ & $\begin{array}{l}0-30,000 \mathrm{ppm} \\
\text { (n-Hexane) }\end{array}$ & $1 \mathrm{ppm}$ & \pm 4 ppm abs. \\
\hline $\mathrm{CO}$ & $0-15 \%$ & $0.001 \%$ & $\pm 0.02 \%$ abs. \\
\hline $\mathrm{CO}_{2}$ & $0-20 \%$ & $0.01 \%$ & $\pm 0.3 \%$ abs. \\
\hline $\mathrm{O}_{2}$ & $0-25 \%$ & $0.01 \%$ & $\pm 0.1 \%$ abs. \\
\hline $\mathrm{NO}_{\mathrm{x}}$ & $0-5,000 \mathrm{ppm}$ & $1 \mathrm{ppm}$ & \pm 20 ppm abs. \\
\hline
\end{tabular}




\section{Testing Method}

The International Standard ISO 8178-4 C1 testing method was used in this study. This standard is widely used to measure the exhaust emissions of non-road internal combustion engines. Table 4 shows the testing procedure for the $\mathrm{C} 1$ test cycle where the mode is defined as: engine operating point by speed and torque, rated speed. At the start of each test the engine was preconditioned by running the engine at its rated power for 40 minutes. The dynamometer ran a performance curve of the diesel engine and it was found that the engine was not able to reach its rated power of $50.7 \mathrm{~kW}$. From the performance curve it was determined that the maximum torque of the engine occurred at $2300 \mathrm{rpm}$ and as this is less than $60 \%$ of the rated speed the intermediate test speed used instead was $60 \%$ of the rated speed at $1440 \mathrm{rpm}$. The idle speed for the dynamometer is $800 \mathrm{rpm}$, which was chosen as the engine idle speed.

Table 4. ISO 8178-4 test procedure with speed and load values.

\begin{tabular}{lcccccccc}
\hline Mode & 1 & 2 & 3 & 4 & 5 & 6 & 7 & 8 \\
\hline Speed (rpm) & \multicolumn{1}{c}{ Rated speed 2400} & \multicolumn{1}{c}{ Intermediate speed, 1440 } & Idle speed, 80C \\
\hline Torque (N.m) & 180 & 135 & 90 & 18 & 210 & 158 & 105 & 0 \\
Weighting factor & 0.15 & 0.15 & 0.1 & 0.1 & 0.1 & 0.1 & 0.1 & 0.15 \\
\hline
\end{tabular}

\section{RESULTS AND DISCUSSION}

\section{Engine Performance Analysis}

Figure 2 shows the variation of engine output power with the percentage of biodiesel blends. For both biodiesels, the power production of the engine decreases with increase of the biodiesel percentage. This trend is expected. as biodiesel has a lower energy content (Table 1) than fossil diesel [49, 50]. Figure 2 shows a clear comparison between the two biodiesels, where soybean-based biodiesel has a better power output than waste oil biodiesel. It has been found that B5 and B10 have the maximum power output for both biodiesels, which is close to the fossil diesel output power. Soybean biodiesel blends (B5, B10, B15, B20 and B50) produced 0.22\%, 0.44\%, 0.85\%, 1.52\% and 3.05\% less power than diesel fuel, respectively. On the other hand, waste oil biodiesel blends (B5, B10, B15, B20 and B50) produced 0.33\%, 0.65\%, 1.15\%, 2.07\% and 4.24\% less power than diesel fuel, respectively. The result shows that adding biodiesel reduces the power of the engine and the trend of the curve is quite uniform, whereas the value of $R^{2}$ $=0.991$ and 0.988 for soybean biodiesel and waste cooking biodiesel, respectively. For example, the maximum power drops that occurred at B50 for soybean and waste cooking biodiesel were $3.05 \%$ and $4.24 \%$, respectively.

Figure 3 illustrates the maximum output torque variation for each biodiesel blend. Waste cooking biodiesel appears to have the expected effect on torque, as the higher biodiesel content consistently results in a lower maximum torque. By comparing Figure 2 and Figure 3, it is evident that the maximum torque and power reflect each other, which is expected as torque and power are directly related [51]. The total torque output decreases gradually with the increase of biodiesel blends [52]. However, the lower torque production for B50 is expected because the property of the biodiesel blends influenced the in-cylinder combustion in the diesel engine [53]. One of the main reasons is that soybean oil contains more than $55 \%$ of linoleic acid, which may cause a more viscous fuel when mixing 50\% with fossil diesel [54]. The decrease of brake power and torque can be attributed to the biodiesel blends due to the lower energy 
content (Table 1) and higher viscosity [55]. For soybean biodiesel, 0.45\%, $0.91 \%$, $1.59 \%, 2.27 \%$ and $3.18 \%$ less torque was produced for the B5, B10, B15, B20 and B50 blends, respectively. On the contrary, waste cooking biodiesel blends (B5, B10, B15, B20 and B50) produced $0.68 \%, 1.36 \%, 2.05 \%, 2.73 \%$ and $3.64 \%$ less torque compared with diesel fuel, respectively. According to these performance curves (Figure 3), soybean biodiesel $\left(R^{2}=0.999\right)$ has better performance than waste cooking biodiesel $\left(R^{2}\right.$ $=0.998)$. Lambda values from 1.05 to 1.26 have been used for this experiment. The air/fuel ratio was 15.2 to 18.3 . Both varied with different rpm.

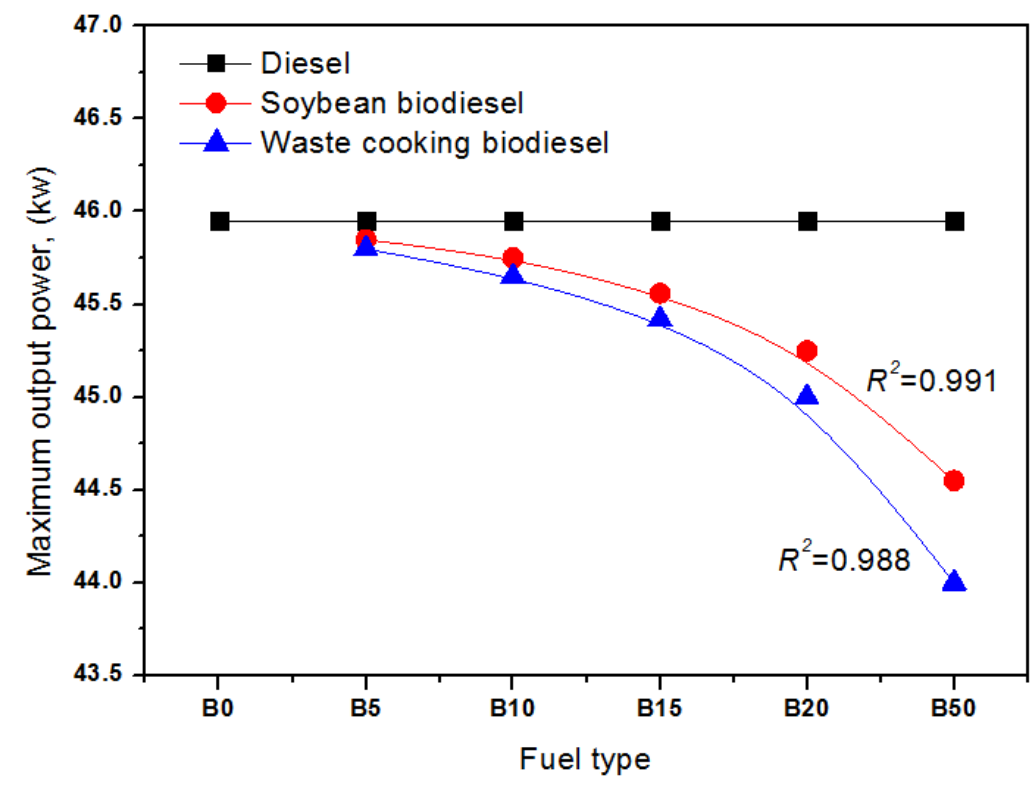

Figure 2. Comparison of maximum output power of diesel and different biodiesel blends.

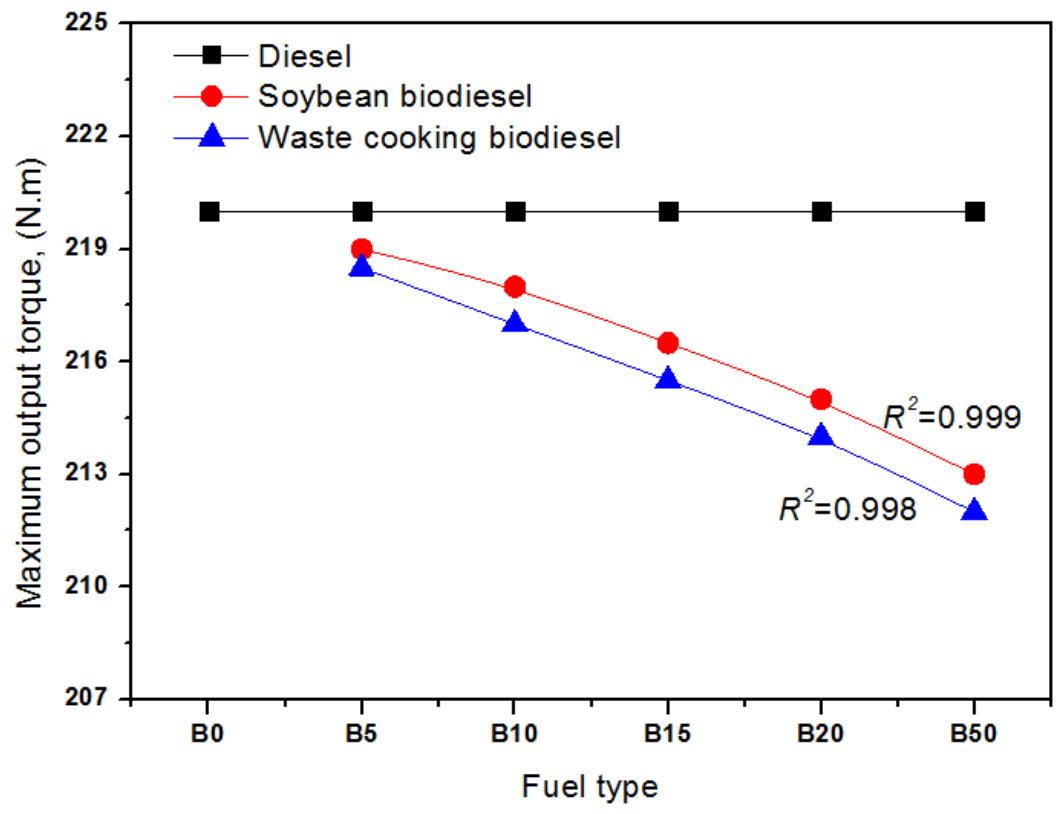

Figure 3. Maximum output torque measured in test engine for diesel and different biodiesel blends. 


\section{Brake Specific Fuel Consumption}

BSFC is an important factor for engine performance of the fuel. Figure 4 shows the variation of BSFC for different fuel blends over the ISO 8178 test procedure. Fuel flow was calculated in the same way as the emissions, with readings taken at each of the modes and weighting factors applied to get an overall fuel consumption. As shown from Figure 4, biodiesels have higher BSFC than fossil diesel [56]. However, the fuel consumption for B5 soybean biodiesel is lower than other blends. Compared with waste cooking biodiesel blends, soybean biodiesel has lower BSFC except for the B50 blends. The trends of this curve are acceptable according to the literature, as biodiesel has greater fuel consumption due to its lower energy content (Table 1) and higher density [57]. With soybean biodiesel $\left(R^{2}=0.965\right)$ the amount of fuel used increases with the biodiesel percentage. BSFC increases for B5, B10, B20 and B50 as 6.05\%, 9.13\%, $12.36 \%$ and $18.57 \%$ more than diesel, respectively. For waste oil biodiesel $\left(R^{2}=0.997\right)$, BSFC increases from B5 to B20 constantly, but for B50 a slightly lower BSFC has been found. The BSFC is $8.17 \%, 11.40 \%, 17.71 \%$ and $14.96 \%$ higher for B5, B10, B20 and B50 compared with fossil diesel, respectively. It has been reported that BSFC increases with the increase of biodiesel blends [58]. So, the experimental results are acceptable according to the literature $[59,60]$. The greater fuel consumption can be attributed to the lower energy content (Table 1) of biodiesel blends compared with fossil diesel. So, soybean biodiesel blends show better performance considering total output power, torque and BSFC compared with waste cooking biodiesel.

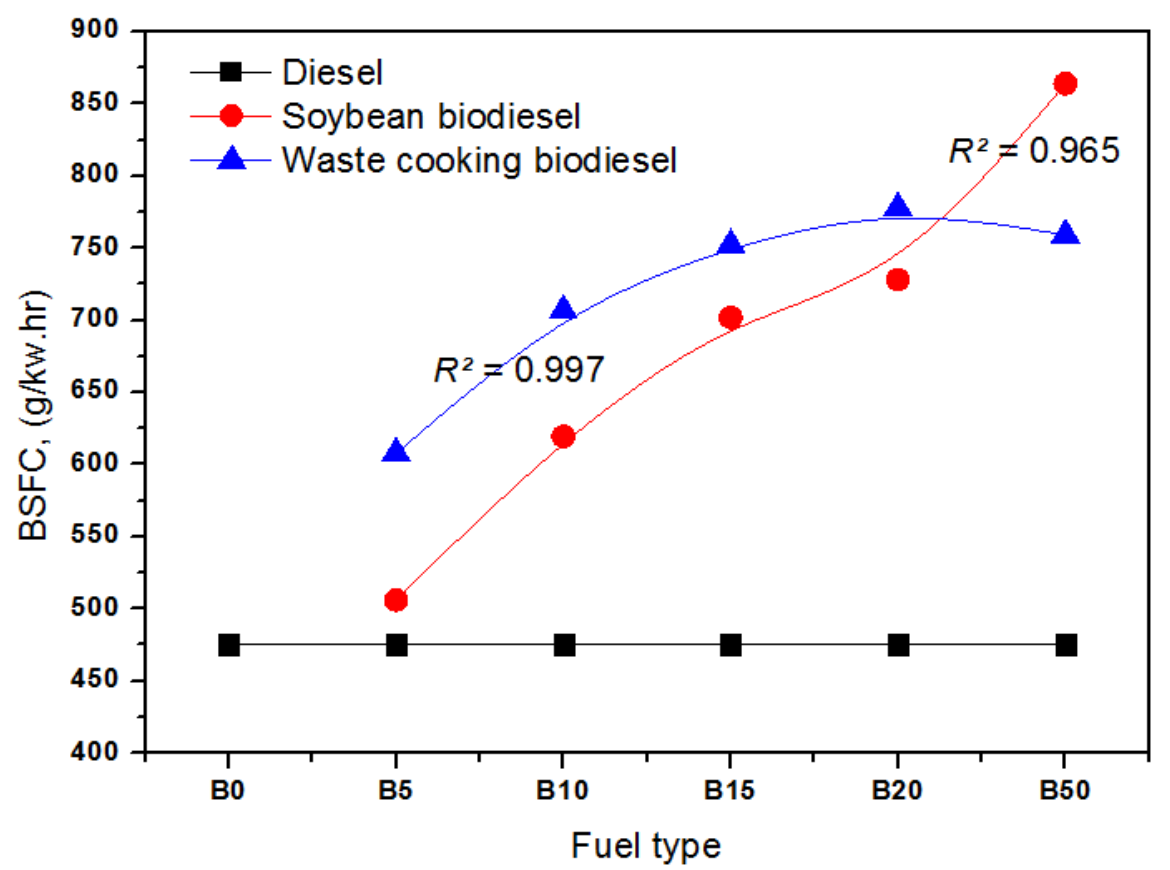

Figure 4. Comparison of brake specific fuel consumption for diesel and biodiesel blends.

\section{Emission Analysis}

Emission analysis is an important part of fuel testing in CI engines. In this experiment, $\mathrm{CO}, \mathrm{CO}_{2}, \mathrm{HC}$ and $\mathrm{NO}_{\mathrm{x}}$ emissions have been considered as emission parameters for the diesel and both biodiesels. For this purpose, a gas analyser was installed in the exhaust pipe of the experimental setup. The results of the analysis are briefly discussed below. 


\section{Carbon dioxide $\left(\mathrm{CO}_{2}\right)$ emission}

Figure 5 shows the comparison of $\mathrm{CO}_{2}$ emissions for the three different test fuels under the ISO 8178 test procedure. It can be seen that the results obtained are different for the two biodiesels. The literature reported that biodiesel is a carbon-neutral fuel and the combustion of biodiesel in CI engines emits lower greenhouse gases than fossil diesel $[61,62]$.

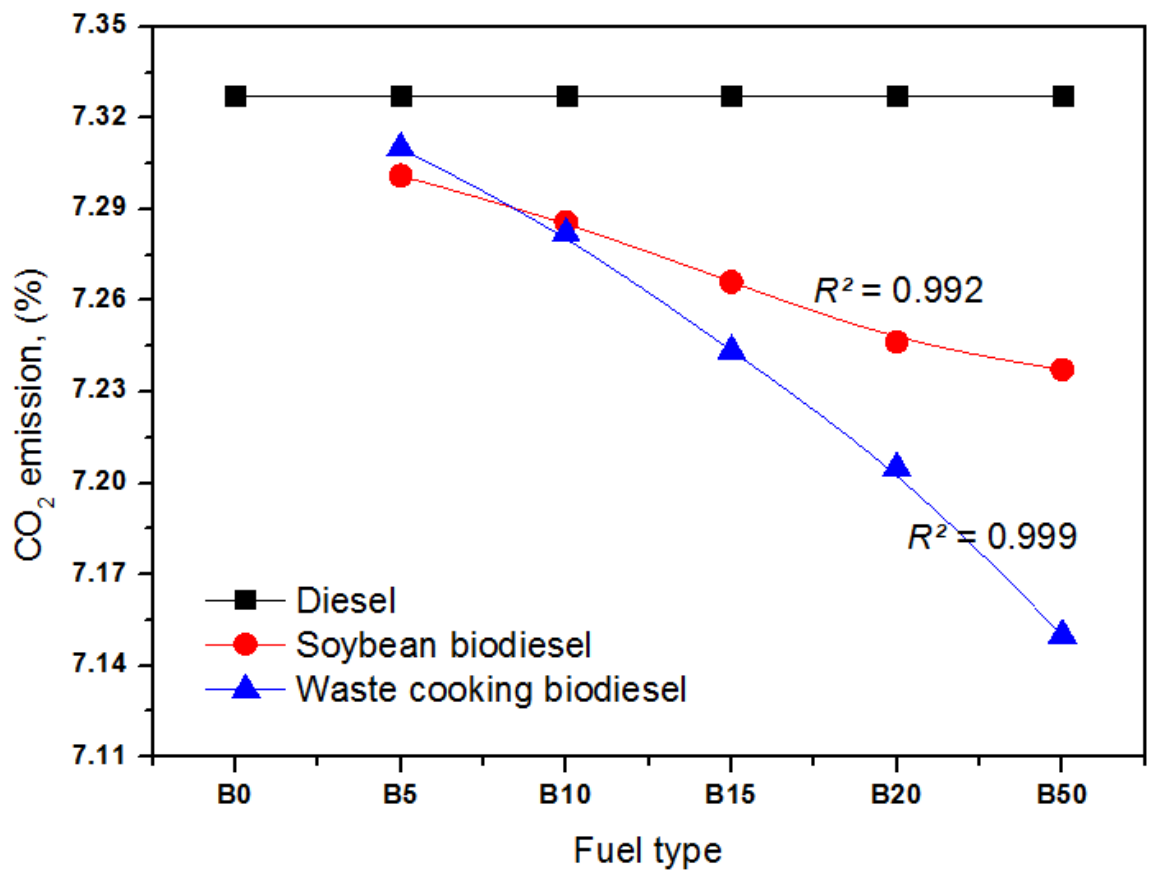

Figure 5. Comparative study of $\mathrm{CO}_{2}$ emission for diesel and different biodiesel blends.

The trend shows the decrease in $\mathrm{CO}_{2}$ emission with the increase of biodiesel percentage. For soybean biodiesel, $0.36 \%, 0.56 \%, 0.83 \%, 1.10 \%$ and $1.23 \%$ reduction of $\mathrm{CO}_{2}$ emission was recorded for B5, B10, B15, B20 and B50 blends compared with diesel fuel, respectively. Besides, $0.23 \%, 0.62 \%, 1.14 \%, 1.67 \%$ and $2.42 \%$ reduction of $\mathrm{CO}_{2}$ emission was observed for waste cooking biodiesel blends, respectively. The trend of reduction for soybean biodiesel (where $R^{2}=0.992$ ) is higher than for waste cooking biodiesel (where $R^{2}=0.999$ ). The waste cooking biodiesel has a more distinct trend as the more biodiesel is added to the fuel, the more $\mathrm{CO}_{2}$ emissions are given off. The highest $\mathrm{CO}_{2}$ reduction occurred using the B50 blend of waste oil biodiesel. The B20 and $\mathrm{B} 50$ waste oil biodiesel blends have lower $\mathrm{CO}_{2}$ readings than diesel fuel.

\section{Carbon monoxide (CO) emission}

The literature has reported that $\mathrm{CO}$ emissions occur when no excess oxygen is present in the fuel [63]. Some other factors, namely, air/fuel ratio, injection timing, engine speed, injection pressure, fuel characteristics etc. are also related to the $\mathrm{CO}$ emission by combustion of fuel in CI engines [64]. Figure 6 shows the variation of $\mathrm{CO}$ emissions of the three different fuels, where the majority of the biodiesel emits less $\mathrm{CO}$ compared with diesel's CO emissions. For soybean biodiesel, the trend (where $R^{2}=0.995$ ) shows $15.49 \%, 24.83 \%, 30.48 \%, 36.13 \%$ and $42.79 \%$ reduction of CO emission compared with diesel for the B5, B10, B15, B20 and B50 blends, respectively. On the other hand, waste cooking biodiesel emits the lowest $\mathrm{CO}$ emission compared with soybean 
biodiesel. The reduction of $\mathrm{CO}$ emission is recorded as $28.45 \%, 36.03 \%, 40.96 \%$, $45.89 \%$ and $52.32 \%$ compared to diesel for the B5, B10, B15 B20 and B50 biodiesel blends, respectively. The trends for $\mathrm{CO}$ emission are quite uniform for both biodiesels, where the value of $R^{2}$ is 0.995 . The experimental data shows that the amount of waste cooking biodiesel has a significant effect on $\mathrm{CO}$, with the results falling between 140 and $180 \mathrm{ppm}$ for blends between 5 and 50\% biodiesel. B50 soybean biodiesel has slightly over a $50 \%$ reduction in $\mathrm{CO}$ emissions. The lower $\mathrm{CO}$ reading for the different biodiesels could be attributed to biodiesel having higher oxygen content [65, 66]. A higher oxygen content results in more complete combustion and less $\mathrm{CO}$ emission in the exhaust. So, the waste oil biodiesel blends are better from the $\mathrm{CO}$ emission point of view.

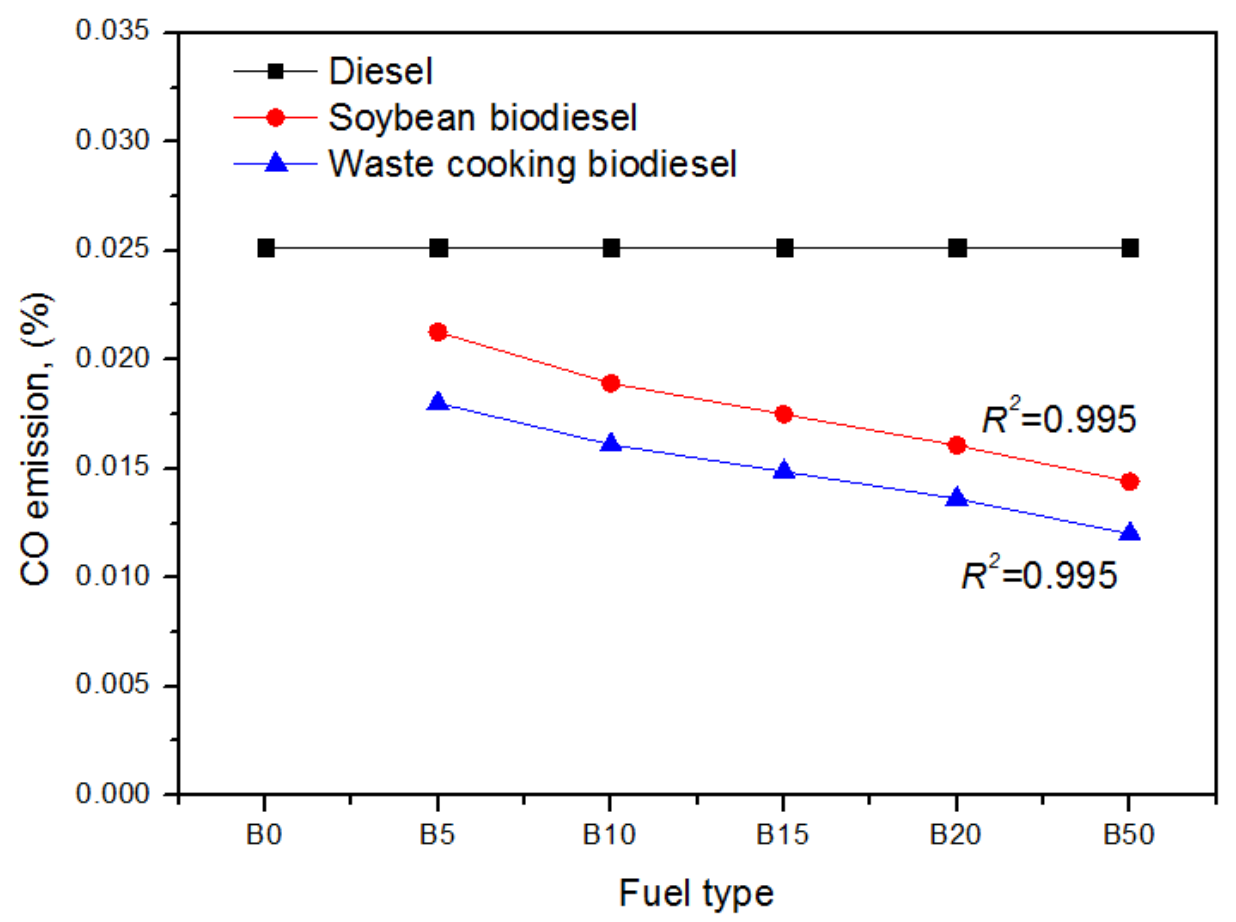

Figure 6. Comparative study of CO emission for diesel and different biodiesel blends.

\section{Hydrocarbon (HC) emission}

Figure 7 shows the $\mathrm{HC}$ in the exhaust stream for the three different test fuels under the ISO 8178 test procedure. Incomplete combustion of fuel and flame quenching results in the unburned $\mathrm{HC}$ emission in CI engines $[67,68]$. This occurs when laminar flames enter a region of intense turbulence without a mean flow at instantaneous temperature [69]. As shown in Figure 7, the trends of $\mathrm{HC}$ emission for both biodiesels are uniform, where the values of $R^{2}$ are 0.988 and 0.995 for soybean and waste cooking biodiesel, respectively. The United States Environmental Protection Agency (US EPA) determined that with an increase in biodiesel the amount of hydrocarbons in the exhaust stream should decrease [70]. The results obtained from this testing for $\mathrm{HC}$ emissions are inconclusive and only follow the US EPA statement for the B10, B20 waste oil biodiesel blends and B50 soybean biodiesel. All other blends have a positive impact on $\mathrm{HC}$ emission compared with diesel fuel. A reason for these results varying so much is because hydrocarbons make up a very small amount of the exhaust stream [71]. The maximum $\mathrm{HC}$ reading was $18 \mathrm{ppm}$, which equates to $0.0018 \%$ of the exhaust gas. 


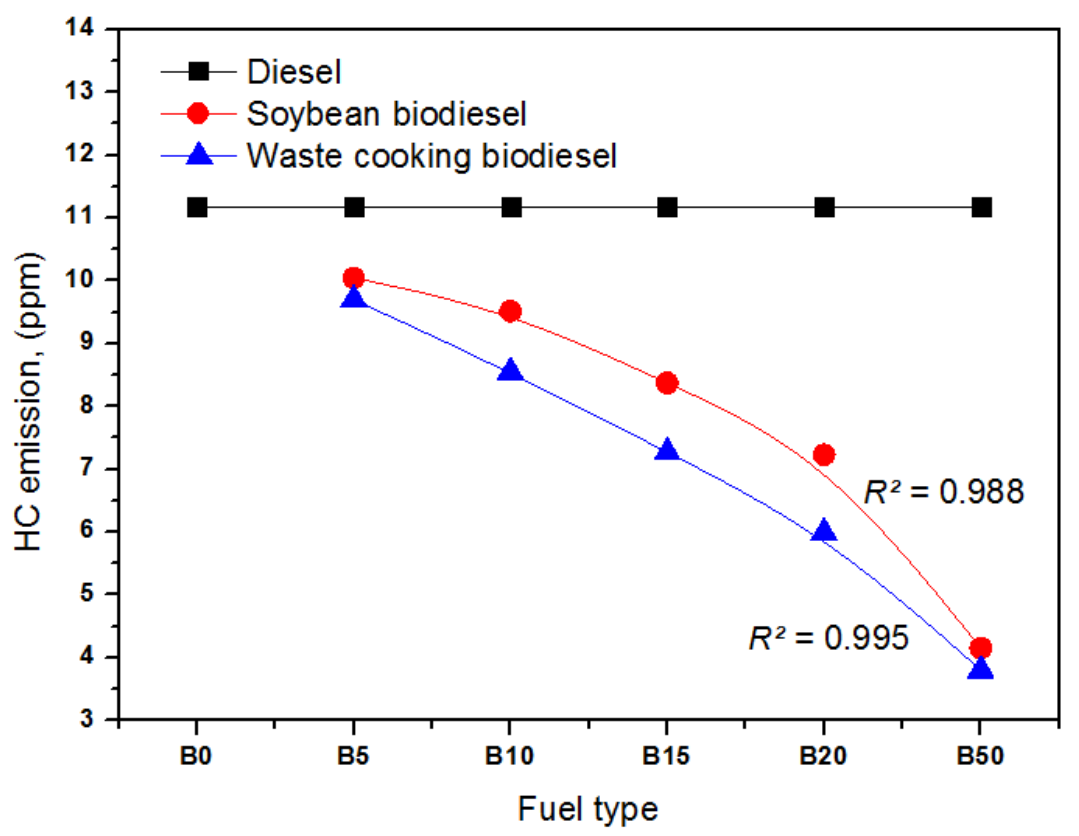

Figure 7. Comparative study of HC emission for diesel and different biodiesel blends.

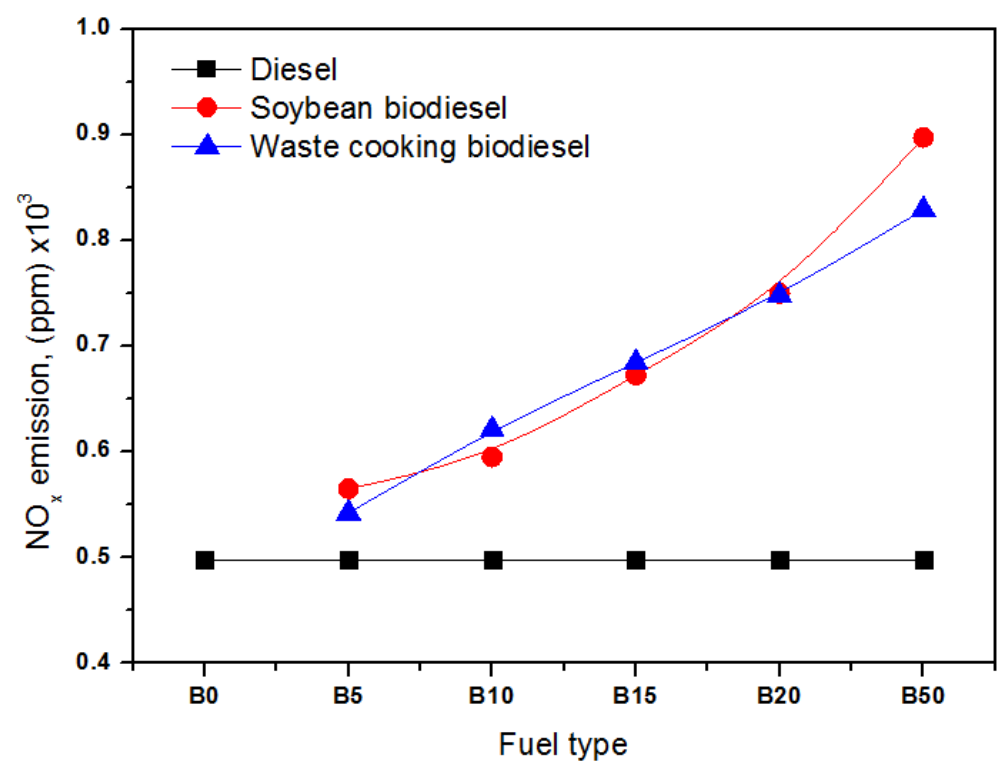

Figure 8. Comparative study of $\mathrm{NO}_{\mathrm{x}}$ emission for diesel and different biodiesel blends.

Figure 8 illustrates $\mathrm{NO}_{\mathrm{x}}$ emission by combustion of biodiesels in $\mathrm{CI}$ engines under the ISO 8178 test procedure. These is evidence from previous studies that $\mathrm{NO}_{\mathrm{x}}$ emission is one of the most important problems with the combustion of biodiesel in CI engines [58]. From the graph, it is clearly seen that biodiesels have a positive impact on $\mathrm{NO}_{\mathrm{x}}$ emission compared with diesel fuel. For soybean biodiesel, $\mathrm{NO}_{\mathrm{x}}$ emission increases by $13.57 \%, 19.60 \%, 35.18 \%, 50.75 \%$ compared with diesel fuel for the B5, B10, B20 and $\mathrm{B} 50$ biodiesel blends, respectively. Besides, $\mathrm{NO}_{\mathrm{x}}$ emission by combustion of $\mathrm{B} 5, \mathrm{~B} 10$, B20 and B50 waste cooking biodiesel blends leads to increases of $8.94 \%, 24.82 \%$, 
$37.59 \%$ and $50.35 \%$ of $\mathrm{NO}_{\mathrm{x}}$ emission compared with fossil diesel, respectively. The comparison between soybean and waste oil biodiesel shows that the B10 blend of soybean biodiesel emits lower $\mathrm{NO}_{\mathrm{x}}$ emission than other blends, as well as other biodiesel. Both biodiesels show increasing trends of $\mathrm{NO}_{\mathrm{x}}$ emission. The US EPA report shows that an increase in biodiesel percentage leads to increase of $\mathrm{NO}_{\mathrm{x}}$ emissions. As discussed earlier, $\mathrm{NO}_{\mathrm{x}}$ has a global warming potential of nearly 300 , meaning that it is 300 times worse for the atmosphere than $\mathrm{CO}_{2}$ emission [66]. So, the small amounts of NOx emission have greater importance than the other exhaust emissions.

\section{CONCLUSIONS}

The study experimentally investigated the use of biodiesel as an alternative fuel for diesel engines. The following conclusions can be drawn from the study. The characteristics of these biodiesels and their blends meet the requirement of ASTM D6751 and EN 14214 standards. The ISO 8178 test procedure was followed during the engine performance test and emission study and it was found that biodiesel produced less power and torque and higher BSFC than diesel fuel. The overall performance of B5 and B10 soybean biodiesel was found to be better than other biodiesel blends. These two blends produced $45.85 \mathrm{~kW}$ and $218 \mathrm{Nm}$ output power and torque, which are only $0.22 \%$ and $0.92 \%$ lower power and torque production values compared to diesel fuel. The BSFC of soybean biodiesel is lower than waste oil biodiesel but slightly higher than diesel. With the various emission gases such as $\mathrm{CO}, \mathrm{CO}_{2}, \mathrm{HC}$ and $\mathrm{NO}_{\mathrm{x}}$, there were no evident trends for the two biodiesels, but for $\mathrm{NO}_{\mathrm{x}}$ emission the soybean biodiesel has lower values than waste oil biodiesel. So the soybean biodiesel is better than waste cooking biodiesel.

\section{ACKNOWLEDGMENTS}

This work was conducted under the Strategic Research Scholarship funded by the Central Queensland University, Australia.

\section{REFERENCES}

[1] Azad AK, Rasul MG, Khan MMK, Sharma SC, Hazrat MA. Prospect of biofuels as an alternative transport fuel in Australia. Renewable and Sustainable Energy Reviews. 2015;43:331-51.

[2] Panwar NL, Shrirame HY, Rathore NS, Jindal S, Kurchania AK. Performance evaluation of a diesel engine fueled with methyl ester of castor seed oil. Applied Thermal Engineering. 2010;30:245-9.

[3] Azad AK, Rasul MG, Khan MMK, Ahasan T, Ahmed SF. Energy scenario: production, consumption and prospect of renewable energy in Australia. Journal of Power and Energy Engineering. 2014;2:19-25.

[4] Ball A, Feng A, McCluskey C, Pham P, Stanwix G, Willcock T. Australian energy update. bureau of resources and energy economics. (cited on 29 August 2014); Available from: <http://www.bree.gov.au/publications/australian-energystatistics>. 2014.

[5] Azad AK, Uddin SMA. Performance study of a diesel engine by first generation bio-fuel blends with fossil fuel: An experimental study. Journal of Renewable and Sustainable Energy. 2013;5:013118(1-12). 
[6] Vashist D, Ahmad M. Statistical Analysis of Diesel Engine Performance for Castor and Jatropha Biodiesel-Blended Fuel. International Journal of Automotive and Mechanical Engineering. 2014;10:2155-69.

[7] Rostami S, Ghobadian B, Kiani Deh Kiani M. Effect of the Injection Timing on the Performance of a Diesel Engine Using Diesel-Biodiesel Blends. International Journal of Automotive and Mechanical Engineering. 2014;10:1945-58.

[8] Kumaran P, Gopinathan M, Kantharrajan S. Combustion Characteristics of Improved Biodiesel in Diffusion Burner. International Journal of Automotive and Mechanical Engineering. 2014;10:2112-21.

[9] Amir Uddin MA, Azad AK. Diesel Engine Performance Study for Bio-fuel: Vegetable oil, A Alternative Source of Fuel. International Journal of Energy Machinery 2012;5:8-17.

[10] Mofijur M, Atabani AE, Masjuki HH, Kalam MA, Masum BM. A study on the effects of promising edible and non-edible biodiesel feedstocks on engine performance and emissions production: A comparative evaluation. Renewable and Sustainable Energy Reviews. 2013;23:391-404.

[11] Azad AK, Rasul MG, Khan MMK, Sharma SC. Review of non-edible biofuel resources in Australia for second generation (2G) biofuel conversion International Green Energy Conference. Tainjin, China2014. p. 867-78.

[12] Atabani AE, Silitonga AS, Ong HC, Mahlia TMI, Masjuki HH, Badruddin IA, et al. Non-edible vegetable oils: A critical evaluation of oil extraction, fatty acid compositions, biodiesel production, characteristics, engine performance and emissions production. Renewable and Sustainable Energy Reviews. 2013;18:211-45.

[13] McCarthy P, Rasul M, Moazzem S. Comparison of the performance and emissions of different biodiesel blends against petroleum diesel. International Journal of Low-Carbon Technologies. 2011:ctr012.

[14] Azad AK, Rasul MG, Khan MMK, Sharma SC. Review of biodiesel production from microalgae: a novel source of green energy. International Green Energy Conference. Tainjin, China2014. p. 879-88.

[15] Atadashi IM, Aroua MK, Aziz AA. High quality biodiesel and its diesel engine application: A review. Renewable and Sustainable Energy Reviews. 2010;14:1999-2008.

[16] Azad AK, Ameer Uddin SM, Alam MM. A Comprehensive Study of DI Diesel Engine Performance with Vegetable Oil: An Alternative Bio-fuel Source of Energy. International Journal of Automotive and Mechanical Engineering. 2012;5:576-86.

[17] Escobar JC, Lora ES, Venturini OJ, Yáñez EE, Castillo EF, Almazan O. Biofuels: Environment, technology and food security. Renewable and Sustainable Energy Reviews. 2009;13:1275-87.

[18] Mondal SK, Ferdous K, Uddin MR, Khan MR, Islam MA, Azad AK. Preparation and characterization of biodiesel from karanja oil by using silica gel reactor. 1st international e-conference of energies. Switzerland: Sciforum Electronic Conference Series; 2014. p. 14-31.

[19] Azad AK, Prince MRI. Preparation of bio-diesel from jatropha curcus seeds oil: performance and emission study of a 4-stroke single cylinder biodiesel fueled engine. International Journal of Energy and Technology. 2012;4:1-6. 
[20] Said NH, Ani FN, Said MFM. Review of the production of biodiesel from waste cooking oil using solid catalysts. Journal of Mechanical Engineering and Sciences. 2015;8:1302-11.

[21] Rahim R, Mamat R, Taib MY, Abdullah AA. Influence of fuel temperature on a diesel engine performance operating with biodiesel blended. Journal of Mechanical Engineering and Sciences. 2012;2:226-36.

[22] Ghobadian B, Najafi G, Nayebi M. A semi-empirical model to predict diesel engine combustion parameters. Journal of Mechanical Engineering and Sciences. 2013;4:373-82.

[23] Kim S, Dale BE. Life cycle assessment of various cropping systems utilized for producing biofuels: Bioethanol and biodiesel. Biomass and Bioenergy. 2005;29:426-39.

[24] Azad AK, Rasul MG, Khan MMK, Omri A, Bhuiya MMK, Ali MH. Modelling of renewable energy economy in Australia. Energy Procedia. 2014:1902-6.

[25] Azad AK, Rasul MG, Khan MMK, Sharma SC. Socio-economic prospect of second generation bio-fuel in Australia: A Review International Conference on Clean Energy Istanbul, Turkey2014. p. 210-21.

[26] Bhuiya MMK, Rasul MG, Khan MMK, Ashwath N, Azad AK, Hazrat MA. Second Generation Biodiesel: Potential Alternative to-Edible Oil-Derived Biodiesel. Energy Procedia. 2014:1969-72.

[27] Azad AK, Uddin SMA, Alam MM. Mustard oil, an alternative Fuel: An experimental investigation of Bio-diesel properties with and without Transesterification reaction. Global Advanced Research Journal of Engineering, Technology and Innovation. 2012;1:75-84.

[28] Atabani AE, Silitonga AS, Badruddin IA, Mahlia TMI, Masjuki HH, Mekhilef S. A comprehensive review on biodiesel as an alternative energy resource and its characteristics. Renewable and Sustainable Energy Reviews. 2012;16:2070-93.

[29] Dizge N, Keskinler B, Tanriseven A. Biodiesel production from canola oil by using lipase immobilized onto hydrophobic microporous styrene-divinylbenzene copolymer. Biochemical Engineering Journal. 2009;44:220-5.

[30] Antolın G, Tinaut F, Briceno Y, Castano V, Perez C, Ramırez A. Optimisation of biodiesel production by sunflower oil transesterification. Bioresource technology. 2002;83:111-4.

[31] McCarthy P, Rasul M, Moazzem S. Analysis and comparison of performance and emissions of an internal combustion engine fuelled with petroleum diesel and different bio-diesels. Fuel. 2011;90:2147-57.

[32] Azad AK, Rasul MG, Khan MMK, Sharma SC, Bhuiya MMK, Mofijur M. A Review on Socio-economic Aspects of Sustainable Biofuels. International Journal of Global Warming. 2016:(Accepted).

[33] Silitonga A, Masjuki H, Mahlia T, Ong H, Chong W, Boosroh M. Overview properties of biodiesel diesel blends from edible and non-edible feedstock. Renewable and Sustainable Energy Reviews. 2013;22:346-60.

[34] Sanjid A, Masjuki H, Kalam M, Rahman S, Abedin M, Palash S. Impact of palm, mustard, waste cooking oil and Calophyllum inophyllum biofuels on performance and emission of CI engine. Renewable and Sustainable Energy Reviews. 2013;27:664-82.

[35] Rahman SMA, Masjuki HH, Kalam MA, Abedin MJ, Sanjid A, Sajjad H. Production of palm and Calophyllum inophyllum based biodiesel and investigation of blend performance and exhaust emission in an unmodified 
diesel engine at high idling conditions. Energy Conversion and Management. 2013;76:362-7.

[36] Kim SW, Koo BS, Ryu JW, Lee JS, Kim CJ, Lee DH, et al. Bio-oil from the pyrolysis of palm and Jatropha wastes in a fluidized bed. Fuel Processing Technology. 2013;108:118-24.

[37] Kar T, Keles S. Fast pyrolysis of chestnut cupulae: yields and characterization of the bio-oil. Energy, Exploration \& Exploitation. 2013;31:847-58.

[38] Jahirul MI, Brown JR, Senadeera W, Ashwath N, Laing C, Leski-Taylor J, et al. Optimisation of bio-oil extraction process from beauty leaf (Calophyllum Inophyllum) oil seed as a second generation biodiesel source. Procedia Engineering. 2013;56:619-24.

[39] Bhuiya MMK, Rasul MG, Khan MMK, Ashwath N, Azad AK. Prospects of 2nd generation biodiesel as a sustainable fuel—Part: 1 selection of feedstocks, oil extraction techniques and conversion technologies. Renewable and Sustainable Energy Reviews. 2015;(In Press).

[40] Chauhan BS, Kumar N, Du Jun Y, Lee KB. Performance and emission study of preheated Jatropha oil on medium capacity diesel engine. Energy. 2010;35:248492.

[41] Azad AK, Ameer Uddin SM, Alam MM. Experimental study of DI diesel engine performance using biodiesel blends with kerosene. International Journal of Energy \& Environment. 2013;4:265-78.

[42] Brennan L, Owende P. Biofuels from microalgae-A review of technologies for production, processing, and extractions of biofuels and co-products. Renewable and Sustainable Energy Reviews. 2010;14:557-77.

[43] Campbell MN. Biodiesel: algae as a renewable source for liquid fuel. Guelph Engineering Journal. 2008;1:2-7.

[44] Campbell PK, Beer T, Batten D. Life cycle assessment of biodiesel production from microalgae in ponds. Bioresource Technology. 2011;102:50-6.

[45] Chatzifragkou A, Fakas S, Galiotou-Panayotou M, Komaitis M, Aggelis G, Papanikolaou S. Commercial sugars as substrates for lipid accumulation in Cunninghamella echinulata and Mortierella isabellina fungi. European Journal of Lipid Science and Technology. 2010;112:1048-57.

[46] Chen CY, Yeh KL, Aisyah R, Lee DJ, Chang JS. Cultivation, photobioreactor design and harvesting of microalgae for biodiesel production: a critical review. Bioresource Technology. 2011;102:71-81.

[47] Klocke F, Eisenblatter G. Dry cutting. Annals of CIRP 1997;46:519-26.

[48] Ramadhas AS, Jayaraj S, Muraleedharan C. Biodiesel production from high FFA rubber seed oil. Fuel. 2005;84:335-40.

[49] Basha SA, Gopal KR, Jebaraj S. A review on biodiesel production, combustion, emissions and performance. Renewable and Sustainable Energy Reviews. 2009;13:1628-34.

[50] Hasan MMR, M.M.; Kadirgama, K. A review on homogeneous charge compression ignition engine performance using biodiesel-diesel blend as a fuel. International Journal of Automotive \& Mechanical Engineering. 2015;11:2199211.

[51] Lee CS, Park SW, Kwon SI. An experimental study on the atomization and combustion characteristics of biodiesel-blended fuels. Energy \& fuels. 2005;19:2201-8. 
[52] Vashist D, Ahmad M. Statistical analysis of diesel engine performance for castor and jatropha biodiesel-blended fuel. International Journal of Automotive \& Mechanical Engineering. 2014;10:2155-69.

[53] Kalyani Radha K, Naga Sarada S, Rajagopal K, Nagesh EL. Performance and emission characteristics of CI engine operated on vegetable oils as alternate fuels. International Journal of Automotive and Mechanical Engineering. 2011;4:414-27.

[54] Atadashi I, Aroua M, Aziz AA. High quality biodiesel and its diesel engine application: a review. Renewable and Sustainable Energy Reviews. 2010;14:1999-2008.

[55] Kapilan N. Improvement of performance of dual fuel engine operated at part load. International Journal of Automotive and Mechanical Engineering (IJAME). 2010;2:200-10.

[56] Hagos FY, Aziz ARA, Sulaiman SA. Syngas (H 2/CO) in a spark-ignition direct-injection engine. Part 1: Combustion, performance and emissions comparison with CNG. International Journal of Hydrogen Energy. 2014;39:17884-95.

[57] Mahgoub BKM, Sulaiman SA, Karim ZAA. Performance Study of Imitated Syngas in a Dual-Fuel Compression Ignition Diesel Engine. International Journal of Automotive \& Mechanical Engineering. 2015;11:2282 - 93.

[58] Mofijur M, Masjuki HH, Kalam MA, Atabani AE, Arbab MI, Cheng SF, et al. Properties and use of Moringa oleifera biodiesel and diesel fuel blends in a multi-cylinder diesel engine. Energy Conversion and Management. 2014;82:169-76.

[59] Wang X, Ge Y, Yu L, Feng X. Comparison of combustion characteristics and brake thermal efficiency of a heavy-duty diesel engine fueled with diesel and biodiesel at high altitude. Fuel. 2013;107:852-8.

[60] Shahabuddin M, Masjuki H, Kalam M, Mofijur M, Hazrat M, Liaquat A. Effect of additive on performance of CI engine fuelled with bio diesel. Energy Procedia. 2012;14:1624-9.

[61] Azad AK, Rasul MG, Khan MMK, Sharma SC, Islam R. Prospect of Moringa seed oil as a sustainable biodiesel fuel in Australia: A review. Procedia Engineering. 2015;105:601-6.

[62] Usta N, Öztürk E, Can Ö, Conkur E, Nas S, Con A, et al. Combustion of biodiesel fuel produced from hazelnut soapstock/waste sunflower oil mixture in a diesel engine. Energy Conversion and Management. 2005;46:741-55.

[63] Rahman MM, Hassan MH, Kalam MA, Atabani AE, Memon LA, Rahman SMA. Performance and emission analysis of Jatropha curcas and Moringa oleifera methyl ester fuel blends in a multi-cylinder diesel engine. Journal of Cleaner Production. 2014;65:304-10.

[64] Gumus M, Sayin C, Canakci M. The impact of fuel injection pressure on the exhaust emissions of a direct injection diesel engine fueled with biodiesel-diesel fuel blends. Fuel. 2012;95:486-94.

[65] Ghobadian B, Rahimi H, Nikbakht A, Najafi G, Yusaf T. Diesel engine performance and exhaust emission analysis using waste cooking biodiesel fuel with an artificial neural network. Renewable Energy. 2009;34:976-82.

[66] Lapuerta M, Herreros JM, Lyons LL, García-Contreras R, Briceño Y. Effect of the alcohol type used in the production of waste cooking oil biodiesel on diesel performance and emissions. Fuel. 2008;87:3161-9. 
[67] Daniel W. Flame quenching at the walls of an internal combustion engine. Symposium (International) on Combustion: Elsevier; 1957. p. 886-94.

[68] Blank DA, Pouring AA, Lu J. Flame Quenching in the Micro-Chamber Passages of IC Engines with Regular-Symmetric Sonex Piston Geometry. 2001.

[69] Chomiak J, Jarosiński J. Flame quenching by turbulence. Combustion and Flame. 1982;48:241-9.

[70] United States Environmental Protection Agency, 2013

[71] Lin YC, Hsu KH, Chen CB. Experimental investigation of the performance and emissions of a heavy-duty diesel engine fueled with waste cooking oil biodiesel/ultra-low sulfur diesel blends. Energy. 2011;36:241-8.

\section{NOMENCLATURE}

\begin{tabular}{|c|c|c|}
\hline $\mathrm{CO}_{2}$ & [\%] & Carbon-di-oxide emission in exhaust gas \\
\hline $\mathrm{CO}$ & {$[\%]$} & Carbon monoxide emission in exhaust gas \\
\hline$H C$ & [ppm] & Hydrocarbon emission \\
\hline$N O_{x}$ & [ppm] & Nitrogen oxides emission \\
\hline$B 5$ & {$[-]$} & $5 \%$ biodiesel, $95 \%$ diesel, by volume \\
\hline$B 10$ & {$[-]$} & $10 \%$ biodiesel, $90 \%$ diesel, by volume \\
\hline$B 20$ & {$[-]$} & B20\% biodiesel, $80 \%$ diesel, by volume \\
\hline$B 50$ & {$[-]$} & $50 \%$ biodiesel, $50 \%$ diesel, by volume \\
\hline$B S F C$ & [kg/kw.h] & Brake specific fuel consumption \\
\hline
\end{tabular}

